Uniwersytet PrzyrodniczoHumanistyczny w Siedlcach

Siedlce University of Natural Sciences and Humanities

https://bazawiedzy.uph.edu.pl

\begin{tabular}{|l|l|}
\hline Publikacja / Publication & $\begin{array}{l}\text { The automotive sector in Spain. Influence of R\&D investment on the improvement of } \\
\text { total factor productivity, } \\
\text { Miró-Pérez Albert-P, Crisóstomo Gálvez Raquel, Carreño Marc Valderrama }\end{array}$ \\
\hline $\begin{array}{l}\text { Adres publikacji w Repozytorium } \\
\text { URL / Publication address in } \\
\text { Repository }\end{array}$ & https://bazawiedzy.uph.edu.pl/info/article/UPHef1d1490dc174030bc86a7b80090933ac/ \\
\hline $\begin{array}{l}\text { Data opublikowania w Repozytorium } \\
\text { / Deposited in Repository on }\end{array}$ & 22 paź 2021 \\
\hline Rodzaj licencji / Type of licence & Attribution - NonCommercial 3.0 (CC BY-NC 3.0) ○ \\
\hline Cytuj tę wersję / Cite this version & $\begin{array}{l}\text { Miró-Pérez Albert-P, Crisóstomo Gálvez Raquel, Carreño Marc Valderrama: The } \\
\text { automotive sector in Spain. Influence of R\&D investment on the improvement of } \\
\text { total factor productivity, Zeszyty Naukowe Uniwersytetu Przyrodniczo- } \\
\text { Humanistycznego w Siedlcach. Seria: Administracja i Zarzadzanie, Uniwersytet } \\
\text { Przyrodniczo-Humanistyczny (Siedlce), no. 49, 2019, pp. 55-62 }\end{array}$ \\
\hline
\end{tabular}




\title{
THE AUTOMOTIVE SECTOR IN SPAIN. INFLUENCE OF R\&D INVESTMENT ON THE IMPROVEMENT OF TOTAL FACTOR PRODUCTIVITY
}

\author{
SEKTOR MOTORYZACYJNY W HISZPANII. \\ WPŁYW INWESTYCJI W BADANIA I ROZWÓJ NA POPRAWE \\ OGÓLNEJ PRODUKTYWNOŚCI CZYNNIKÓW PRODUKCJI
}

https://doi.org/10.34739/zn.2019.49.06

\author{
Albert-P. Miró-Pérez ${ }^{1}$, Raquel Crisóstomo Gálvez ${ }^{2}$, Marc Valderrama Carreño ${ }^{3}$ \\ 1 Spain, Vic, University of Vic-UCC \\ ORCID: 0000-0002-9987-6621, e-mail: albertpol.miro@uvic.cat \\ ${ }^{2}$ Spain, Barcelona, ESERP Business School and Law \\ ORCID: 0000-0003-1895-2889, e-mail: rcrisostomo@eserp.com \\ 3 Spain, Barcelona, ESERP Business School and Law \\ ORCID: 0000-0003-4451-5252, e-mail: valderrama.marc@gmail.com
}

\begin{abstract}
The current globalised environment has been preceded by a generalised increase in the diffusion and use of Information and Communication Technologies (ICT), as well as by a large investment in Research and Development $(R \& D)$ by companies. This circumstance makes the use of these technologies fundamental for the automotive sector to face with guarantees the growing international competitivity. Thus, the correct use of ICT provides an improvement in productivity, and therefore in the competitiveness of enterprises. This article analyses the evolution of total factor productivity (TFP) in the Spanish automotive sector for the year 2017, in order to determine the influence this variable has on the improvement of total factor productivity.
\end{abstract}

Keywords: Automotive Sector, R\&D, Total Factor Productivity, Spain

\begin{abstract}
Streszczenie: Obecne zglobalizowane środowisko zostało poprzedzone ogólnym wzrostem rozpowszechnienia i wykorzystania technologii informacyjno-komunikacyjnych (ICT), jak również dużymi inwestycjami przedsiębiorstw w badania i rozwój (R\&D). Okoliczność ta sprawia, że korzystanie z tych technologii ma zasadnicze znaczenie dla sektora motoryzacyjnego i gwarantuje rosnącą konkurencyjność międzynarodową. W związku z tym właściwe wykorzystanie technologii informacyjno-komunikacyjnych zapewnia poprawę wydajności, a tym samym konkurencyjności przedsiębiorstw. W artykule przeanalizowano ewolucję całkowitej produktywności czynników produkcji (TFP) w hiszpańskim sektorze motoryzacyjnym w roku 2017, w celu określenia wpływu tej zmiennej na poprawę całkowitej produktywności czynników produkcji.
\end{abstract}

Słowa kluczowe: sektor motoryzacyjny, badania i rozwój, całkowita produktywność czynników produkcji, Hiszpania

\section{Introduction}

Spain is the second largest manufacturer of vehicles in Europe and the eleventh largest in the world and is a worldwide flagship in terms of aspects such as competitiveness (OICA).

The automotive industry has always been characterized by being the leader in terms of organizational models and production guidelines, as well as by its ability to impose new trends and consumption habits (Martín, 2013). In the Spanish economic context, it represents $10 \%$ of GDP and employs $9 \%$ of the active population (INE).
Apart from the large amount of production covered (with a total of 2,819,565 units in 2018), the automotive sector is the main export sector of the Spanish economy, ahead of the oil and energy industry. In the last year $2018,82 \%$ of the vehicles manufactured in Spain were exported to more than 100 countries, mainly in Europe.

Despite the achievements made by this sector in recent decades, the automotive industry in our country has been affected by the passage of the crisis, when it experienced a significant decline in relation to the number of units produced as compared to the number of exports (Rocha and 
Miró-Pérez A-P., Gálvez R.C., Carreño M.V., THE AUTOMOTIVE SECTOR IN SPAIN. INFLUENCE OF R\&D INVESTMENT ON THE IMPROVEMENT OF TOTAL FACTOR PRODUCTIVITY, Zeszyty Naukowe Uniwersytetu Przyrodniczo-Humanistycznego w Siedlcach $\mathrm{Nr}$ 122, Seria: Administracja i Zarządzanie (49) 2019

Aragon, 2012; Martin, 2013). In 2012, production fell by $32 \%$ to 2 million vehicles produced per year. Currently, although a recovery is observed, it has not yet reached the level of previous years (Albors Garrigós et al., 2017).

The fact that this sector is widely international means that any global crisis affects the Spanish national automotive industry, due to the interrelation within the same sector (Sturgeon et al., 2009). In this case, the situation of instability existing in the United Kingdom (due to Brexit) or Turkey affected the total production in 2017, when it fell by $1.5 \%$ after 5 years of strong increases.

Thus, the automotive industry is in a process of change, a constant evolution directly connected with paradigm shifts in society. This circumstance is directly linked with new information and communication technologies (ICTs). This process of economic globalization associated with the combination of the technological revolution based on the process of digitization have established a new model of society, this is based on the use of knowledge. Thus, these new economic relations are known as the knowledge economy (David and Foray, 2002; Drucker, 2012; Drahos and Braithwaite, 2017).

Under this new socio-economic prism where ICTs and innovation are constantly gaining greater importance, the automotive sector is firmly committed to the challenge of continuous improvement and investment in $\mathrm{R}+\mathrm{D}+\mathrm{i}$ (Morcillo and Alcahud, 2005).

This situation deserves further assertion as it is linked to an improvement in the productivity of companies (Suriñach et al., 2011; Ciuriak et al., 2015). Thus, there is a binding relationship between international competitiveness and innovation in terms of improved productivity. Since this improves the skills of workers or those triggers that come from innovation processes (Corrado et al., 2009; DíazChao and Torrent-Sellens, 2010; Bloom, Sadun and Van Reenen, 2012; Bloom, Draca and Van Reenen, 2016).

The automotive industry is firmly adapting to this new technological paradigm, but its nature as a global sector forces it to face another disruptive change to which it is heading in the new international economic and political context: the threat of a rethinking of the rules of globalisation and free trade and international investment, from both advanced and emerging countries. If this threat is worrying for Europe, it is crucial for Spain in view of the great dependence that the industrial sector has on free access to global value chains (Padilla and Oddone, 2016).
Electrification, robotization, new mobility services, Artificial Intelligence (Al), along with the Internet of Things and virtual reality, are the disruptive trends that will impact the areas of vehicle consumption, driving, production, sales, after-sales and business management (Moyano et al., 2012).

In terms of strategies to adapt and evolve in this globalised world, market pressure has required the adoption of synergies linked to technological development (safety, communication and environmental systems), reflecting the close collaboration between car and component manufacturers, making them outstanding "players" in the market field.

Thus, the work hypothesis is determined by the TFP estimate, which allows us to determine whether there is a positive relationship between the improvement of this variable with respect to the improvement of R\&D investment (Díaz-Chao and Torrent-Sellens, 2010; Miró, 2018).

The objectives set are mainly divided into two:

- Demonstrate the relationship between the use of ICTs in the Spanish automotive sector and the relationship with operating revenues, as well as the improvement of TFP.

- Highlight the relationship between the TFP and the CC.AA.

The rest of the proposed article is outlined as follows: section two shows the reality of the Spanish automobile market, which analyses vehicle production. As well as the commercialization of the same ones in the national and international market. In the third chapter we find the methodology used to contrast the hypothesis raised, as well as the database that will allow us to extract the data from our object of study. The fourth chapter analyses the main results obtained. Finally, the main conclusions obtained are summarised.

\section{Literature review}

\section{Reality of the sector in Spain}

The aim of this section is to show the reality of the Spanish automotive sector, as well as to highlight its main characteristics and its economic relevance. This is why it is important to emphasize the significant characteristics of the sector.

The geographical structure of the industrial fabric of the Spanish automotive market is distributed as can be seen in Figure 1 below. In Spain there are a total of 17 car factories and more than 1,000 component manufacturing companies located in the Autonomous Communities (CC.AA.) of Castile-andLeon, Madrid, Basque Country, Navarre, Aragon, 
Miró-Pérez A-P., Gálvez R.C., Carreño M.V., THE AUTOMOTIVE SECTOR IN SPAIN. INFLUENCE OF R\&D INVESTMENT ON THE IMPROVEMENT OF TOTAL FACTOR PRODUCTIVITY, Zeszyty Naukowe Uniwersytetu Przyrodniczo-Humanistycznego w Siedlcach $\mathrm{Nr}$ 122, Seria: Administracja i Zarządzanie (49) 2019

Valencian Community, Galicia and Catalonia. Between them, a total of 43 car models are manufactured, 20 of them worldwide exclusive. Likewise, it is estimated that for each direct job in the production of automobiles, 4 are generated in the component factories. Both create 300,000 direct jobs and $2,000,000$ indirect jobs, representing $12 \%$ of the manufacturing industry's work.

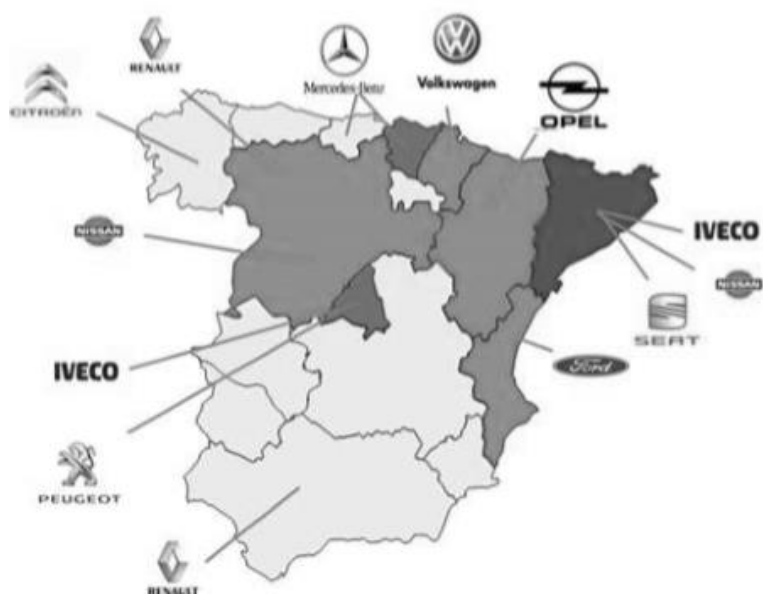

Figure 1. Distribution map of production by brand in Spain Source: produced from Anfac data

\section{Vehicle production}

The most recent data on the situation of the automobile sector in Spain indicate that in 2018 the production of vehicles stood at a total of approximately 2,819,565 units, of which 1,321,438 were registered. It is estimated that in the period 2012-2018 the increase in production has been $42.5 \%$, which means 840,386 additional units, despite the decline in 2017 where production fell by $1.5 \%$.

Thus, the international crisis had an impact on the sector. In 2007, it produced almost 3 million vehicles and Spain ranked fifth in the world as a vehicle manufacturer, second only to China, the United States, Japan and Germany. By 2012, production had already fallen by $32 \%$ to nearly 2 million vehicles. Worldwide, India, Brazil and Mexico produced more than Spain, ranking ninth. Although, from this moment onwards, production has gradually increased until it reached its current values, as can be seen in Figure 2 below.

After analysing the impact of total vehicle production in Spain, the reality is analysed by Autonomous Communities. Castile-and-Leon is the one that produces the most, with $20.36 \%$ of the total, followed by Catalonia (with 19.24\%), Galicia (15.27\%), Valencian Community (14.64\%) and Aragon $(13.43 \%)$. They are followed by the
Autonomous Communities of Navarre, with $8.57 \%$, then the Basque Country, with $5.28 \%$ and Madrid, with only $3.22 \%$ of total production. In all of them, last year there was an increase in sales compared to 2017, with the exception of Catalonia, which suffered a fall of $2.8 \%$ (Figure 3 ).

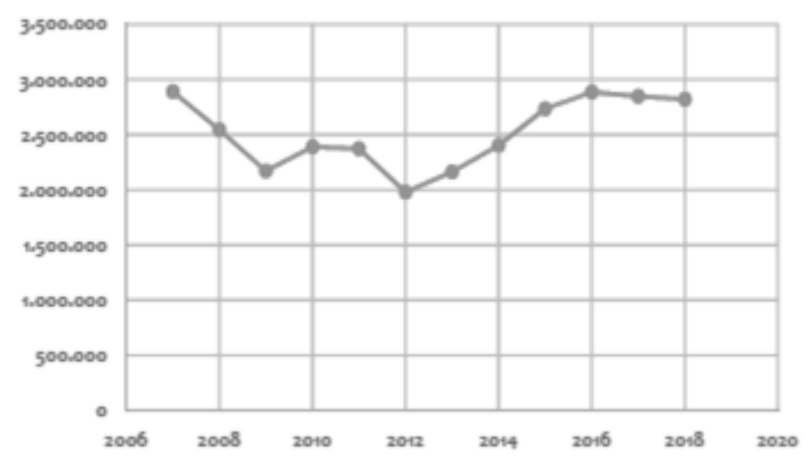

Figure 2. Annual production of manufactured vehicles Source: INE

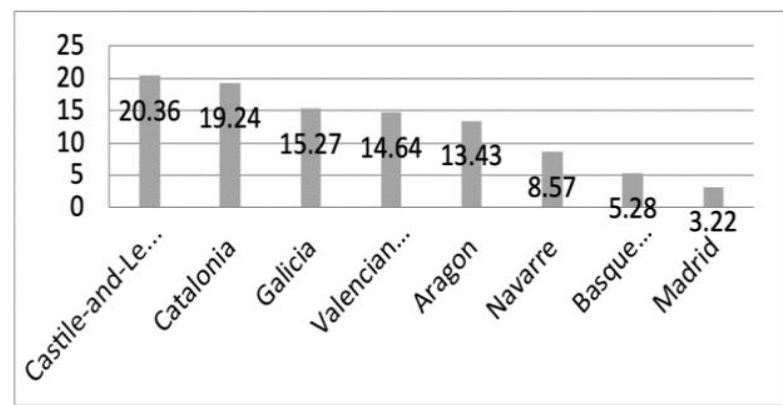

Figure 3. Percentage of vehicle production by Autonomous Community (year 2017) Source: INE

\section{Commercialization}

As for the characteristics of the best-selling vehicles, it is identified on the basis of the type of fuel used. In 2018 , a total of $57.5 \%$ of gasoline-powered vehicles were sold in the Spanish market, compared to $35.8 \%$ of diesel vehicles. It is worth noting that the remaining $6.6 \%$ corresponds to hybrid or electric cars. The latter has experienced remarkable growth compared to 2017 , with a rise of $39.8 \%$, and is the fifth consecutive year in which sales almost doubled $(13,882$ marketed in 2018 compared to 8,611 marketed in 2017).

In terms of vehicle types, the majority of Spaniards prefer utility vehicles, with a total of 289,413 units sold in 2018 , representing a $21.9 \%$ share of the total. Likewise, SUVs maintained their upward trend, whether they were small (with an increase of $35.3 \%$ with respect to the previous year), medium (increase of $20.6 \%$ ) or large (increase of 19.9\%). Exempt are those considered Premium (high range), which lost $4.9 \%$ of sales compared to 
Miró-Pérez A-P., Gálvez R.C., Carreño M.V., THE AUTOMOTIVE SECTOR IN SPAIN. INFLUENCE OF R\&D INVESTMENT ON THE IMPROVEMENT OF TOTAL FACTOR PRODUCTIVITY, Zeszyty Naukowe Uniwersytetu Przyrodniczo-Humanistycznego w Siedlcach $\mathrm{Nr}$ 122, Seria: Administracja i Zarządzanie (49) 2019

the previous year. In relation to the minivans, these represent the most pronounced loss of sales in Spain in relation to $2017,10.7 \%$ less than those of medium size and $23.4 \%$ of those of large size.

If attention is focused on the brand, the one that tops the favourite ranking for Spaniards in the country itself is Seat, which in 2018 sold a total of 107,349 units sold. The second is Volkswagen, which achieved $14.87 \%$ more sales than the previous year, 2017, with 102,968 cars sold. Peugeot follows (with a growth of $15.61 \%$ more than the previous year and 101,502 units sold). Renault and Opel would come next, although with a loss of $5.35 \%$ and $7.59 \%$ of sales respectively. Citroën and Toyota would be in the last positions, with 72,446 and 71,288 and 69,173 units sold, respectively. Finally, Ford $(69,173$ units), Kia $(67,782$ cars) and Hyundai $(64,531$ cars $)$ would be in last place.

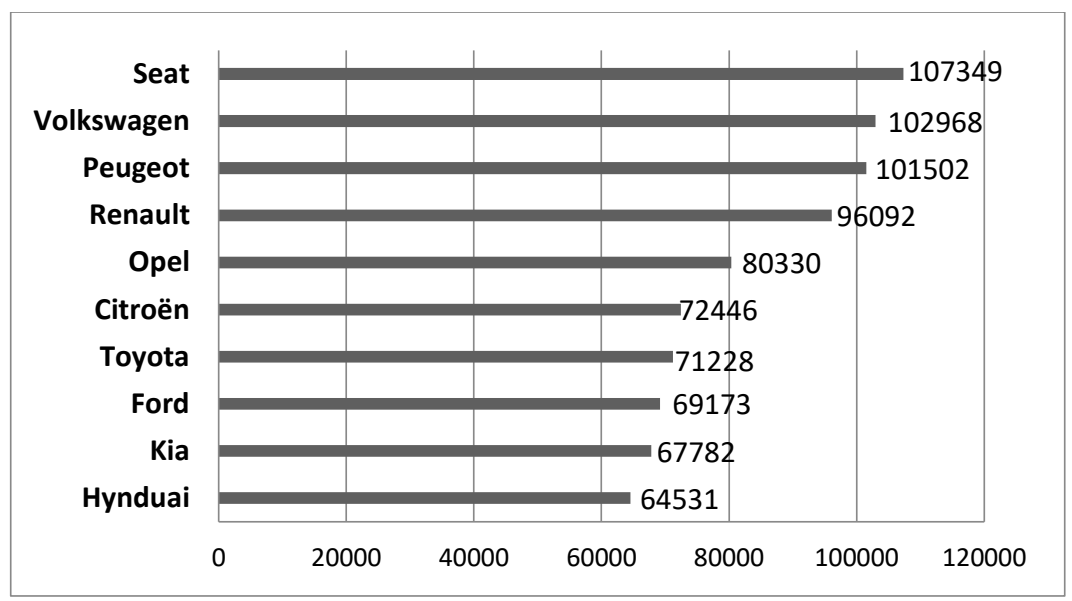

Figure 4. Units of cars sold by brand

Source: produced from Anfac data

\section{Methodology and theoretical basis}

The methodology used in this research is determined by two methods, the first is the Ordinary Square Minimum (OSM) method.

\section{Estimation model}

The model used in this work is based on the estimation of a Cobb-Douglas-type production function with four production factors.

$Y_{i}=A_{i} L_{t}^{O=}{ }^{l} K_{t}^{O={ }_{k}} M_{t}^{O=}{ }_{m}$

Where $Y$ is the added value of the company $i=1, \ldots, N$, which depends on the variable $A$ defined as TFP,

$L$ is the labour factor, $K$ is the quasi-fixed capital factor, $M$ are the intermediate inputs.

In order to be able to work in a linear way, neperian logarithms are applied, which allow the transformation of an exponential function into a linear one, as shown in equation [2]:

$y_{i}=O={ }_{0}+O={ }_{l} l_{i}+O={ }_{k} k_{i}+O={ }_{m} m_{i}+u_{j}$

Where the lowercase letters are precisely the representation of the neperian logarithms. $\beta 0$ is a measure of the TFP level common to all the companies that make up the sample, and $u_{i t}$ represents the error term, which collects all those factors of reality, unobservable or due to external circumstances.

Based on previous literature, the following variables are selected in order to estimate the equation [2], as shown in Table 1.

Table 1. Variables

\begin{tabular}{ll} 
Dependent & Bibliography \\
\hline Added value & Diaz-Chao \& Torrent-Sellens (2010) \\
\hline Independent & \\
\hline Capital & Olley \& Pakes (1996) \\
Material Cost & Olley \& Pakes (1996) \\
Labor Cost & Olley \& Pakes (1996) \\
Source: own elaboration
\end{tabular}

\section{Database: $S A B I$}

In order to carry out an analysis of the different Spanish companies that market vehicles, information provided by the database Iberian Balance Sheet Analysis System (SABI), which provides financial information on Spanish companies since 1990, will be used.

$S A B I$ is the result of the collaboration of three private institutions, Informa D\&B, which is responsible for the database of Spanish companies; Coface Serviços Portugal, SA, responsible for the database of Portuguese companies; and, finally, 
Bureau van Dijk, responsible for the searching software, processing and analysis of data. SABI contains general information and annual accounts of more than $1,000,000$ Spanish companies and 320,000 Portuguese companies.

There is a multitude of literature that uses SABI to adequately extract a database that allows adequate analysis, such as Martí (2014), Llano Molina (2014), Miró (2016), among others.

\section{Results and discussions}

This epigraph presents the main results obtained once the aforementioned methodology has been applied and explained in section 3. Thus, two subsections are shown, the first of which analyses the relationship between TFP and ICT and the Autonomous Community.

\section{Estimated Total Factor Productivity}

This section aims to highlight the main results obtained on the basis of estimates of the CobbDouglas production function, based on the parametric method for a data panel sample. The following Table 2 shows the main estimated parameters of the production function.

However, the other variables have a positive impact with significant values, taking into account the non-significant result of the cost of material. Nonetheless, it is necessary to indicate how to obtain an explanatory value of the high model with an R2 of $97.4 \%$. Next, a multicollinearity analysis is performed using the VIF (Variance Inflation Factor) for the estimation using MCO, obtaining a result that indicates the non-existence of multicollinearity.

As far as that CC.AA. has a better average TFP value can be observed as the Balearic Islands (3.26) has a better TFP index followed by Madrid (2.86) and Aragon (2.37). The average value taken by the Spanish automotive sector is 1.84 , where there are 8 CC.AA. above the average, while the rest is below. It should be noted that since there is no data for the rest of the Autonomous Communities, the analysis is therefore distributed among a total of 15 Autonomous Communities (Table 3).

Table 2. MCO regression

\begin{tabular}{|c|c|c|c|c|c|c|c|c|}
\hline & \multirow{2}{*}{ Model $^{a}$} & \multicolumn{2}{|c|}{ Non-standardized coefficients } & \multirow{2}{*}{$\begin{array}{c}\begin{array}{c}\text { Standardized } \\
\text { coefficients }\end{array} \\
\text { Beta }\end{array}$} & \multirow{2}{*}{$t$} & \multirow{2}{*}{ Sig. } & \multicolumn{2}{|c|}{ Collinearity statistics } \\
\hline & & Coefficients & Standard error & & & & Tolerance & VIF \\
\hline \multirow{4}{*}{1} & (Constant) & 0,805 & 0,181 & & 4,437 & 0,000 & & \\
\hline & InCMat & 0,076 & 0,046 & 0,098 & 1,657 & 0,104 & 0,155 & 6,465 \\
\hline & $\operatorname{lnCL}$ & 0,805 & 0,062 & 0,808 & 13,086 & 0,000 & 0,142 & 7,056 \\
\hline & InCaptial & 0,074 & 0,028 & 0,108 & 2,685 & 0,010 & 0,335 & 2,983 \\
\hline
\end{tabular}

a. Dependent variable: InVA

Source: own elaboration

Table 3. PTF by CC.AA

CC.AA.

\begin{tabular}{ll}
\hline Balearic & 3,26 \\
Madrid & 2,86 \\
Aragon & 2,37 \\
Extremadura & 2,19 \\
Galicia & 2,10 \\
Catalonia & 2,08 \\
Castile-and-Leon & 1,85 \\
\hline Average & $\mathbf{1 , 8 4}$
\end{tabular}

CC.AA.

Medium

Castile-La Mancha

1,78

Basque Country

1,71

Andalusia

1,52

Valencian Community

1,41

Cantabria

1,37

Navarre

1,31

Asturias

1,16

Murcia

Source: own elaboration 
Miró-Pérez A-P., Gálvez R.C., Carreño M.V., THE AUTOMOTIVE SECTOR IN SPAIN. INFLUENCE OF R\&D INVESTMENT ON THE IMPROVEMENT OF TOTAL FACTOR PRODUCTIVITY, Zeszyty Naukowe Uniwersytetu Przyrodniczo-Humanistycznego w Siedlcach Nr 122, Seria: Administracja i Zarządzanie (49) 2019

\section{$R \& D$ in the automotive sector}

The automobile sector is the one that invests the most in R\&D, but it is necessary to continue to promote and invest more in this sector in order to be able to incorporate more cutting-edge technology in the product, as well as in the production process. The sector must be able to innovate and offer new knowledge in order to be technological leaders.

Through applied research, value is added to the product by way of the application of new materials, integrated electrical and electronic systems, electronic mechanics, etc. Whoever achieves more innovation at a reasonable cost differs from other products. Therefore, it is best to look for a combination of differentiation and cost reduction, with a quick response to changes.

At a global level, $R \& D$ projects within the automotive and components sector can be classified into safety, integrated mobility, sustainable propulsion and competitiveness. The automotive industry, in addition to being one of the most powerful economic sectors in the world, has also been one of the sectors where the most has been invested in $R \& D$, in fact is the third place in the world in research (behind the manufacturers of ICT and health).

Brands and countries that make greater investment in R\&D can be seen in the following Table 4. Where it can be highlighted that Volkswagen and General Motors are the main automotive companies that make a large investment in R\&D in 2017. As you can see, Spain is not included. However, it is part of the Volkswagen group, where a large investment is also made in the Spanish market.

Table 4. Automobile brands world ranking in R\&D

\begin{tabular}{cll} 
Position & Brand & Country \\
\hline 1 & Volkswagen & Germany \\
2 & General Motors & United States \\
3 & Daimler & Germany \\
4 & Toyota Motor & Japan \\
5 & Ford Motor & United States \\
6 & Robert Bosch & Germany \\
7 & Honda Motor & Japan \\
8 & BMW & Germany \\
9 & Fiat Chrysler & Netherlands \\
10 & Nissan Motor & Japan \\
11 & Continental & Germany \\
\hline
\end{tabular}

Source: The 2017 EU Industrial R\&D Investment Scoreboard. European Commission
At this point, the question arises: Why invest in R\&D? The answer to this question allows us to determine the directly associated positive externalities such as emission reduction, car software, mobile connections, cloud-based ecosystems, and finally, mobility solutions.

These would be one of the examples of R\&D to make the company more competitive as it is an industry that is exposed to constant change, as is the case of ICT. More and more automotive companies export R\&D in countries outside the base country, in fact between 2007 and 2015 R\&D expenditure increased by $42 \%$. The companies that export the most R\&D are companies based in China and the United States.

Likewise, one of the most important challenges facing the automobile sector is the electric vehicle, which responds to the ever-increasing need to be environmentally sustainable, free of pollutants, etc. On the other hand, the autonomous vehicle is another reality. Some companies that do not belong to the sector have already presented some model, and the automotive sector is running the risk of losing its place and being overtaken by this type of company. The automotive sector has a lot of competition, therefore, for the company to be more competitive and able to be a leader in selling vehicles in the market, it has to innovate.

As with R\&D the automotive company must advance quickly to be more competitive in the market. Not only must we invest more, but so that these can be more profitable, what they are doing are plants called 4.0, that is intelligent production plants.

In such a globalised sector, it is important to have design and engineering centres that come closer to and know the local market and therefore allow for a better ability to react in order to adapt to customer requirements. In order to strengthen the $R \& D$ department it will be necessary to make a significant monetary investment, thus providing it with all the resources and materials necessary to carry out its research. On the other hand, the establishment of a collaboration between the different car brands, in order to create a R\&D\&i department working for the car industry, with the common goal of achieving the maximum technology and performance, as well as the best advances in this sector, would be a solution that would add efforts rather than subtract them. A research centre for R\&D\&i in the automobile sector that could operate, in part, through public money, inasmuch as that what we want to innovate is a social purpose (respectful of 
Miró-Pérez A-P., GálvezR.C., Carreño M.V., THE AUTOMOTIVE SECTOR IN SPAIN. INFLUENCE OF R\&D INVESTMENT ON THE IMPROVEMENT OF TOTAL FACTOR PRODUCTIVITY, Zeszyty Naukowe Uniwersytetu Przyrodniczo-Humanistycznego w Siedlcach $\mathrm{Nr}$ 122, Seria: Administracja i Zarządzanie (49) 2019

the environment, use of non-polluting materials, improvement of road safety, etc.).

Likewise, the estimation by means of the MCO method of the existing relationship between TFP and investment in R\&D\&i (Table 5) shows a positive relationship between both variables, however, the relationship is not significant.

Table 5. Relationship between TFP and R\&D Investment (Bootstrap for coefficients)

\begin{tabular}{|c|c|c|c|c|c|c|c|}
\hline \multirow{3}{*}{\multicolumn{2}{|c|}{ Model }} & \multirow{3}{*}{ B } & \multicolumn{5}{|c|}{ Bootstrap $^{a}$} \\
\hline & & & \multirow{2}{*}{ Bias } & \multirow{2}{*}{ Standard error } & \multirow{2}{*}{ Sig. (bilateral) } & \multicolumn{2}{|c|}{$95 \%$ confidence interval } \\
\hline & & & & & & Inferior & Superior \\
\hline \multirow{2}{*}{1} & (Constant) & 1,314 & $-0,097^{b}$ & $0,698^{b}$ & $0,330^{\mathrm{b}}$ & $0,298^{b}$ & $2,258^{b}$ \\
\hline & InInv2017 & 0,134 & $0,033^{b}$ & $0,117^{b}$ & $0,330^{b}$ & $0,024^{b}$ & $0,345^{b}$ \\
\hline
\end{tabular}

a. Unless otherwise indicated, bootstrap results are based on 1000 bootstrap samples

b. Based on 884 samples

Source: own elaboration

\section{Conclusions}

The automotive sector is a good example of industrial globalisation. Industrial manufacturing is considered the engine of the economy in the most developed countries and the automobile is one of their greatest tractors. Spain faces the challenge of modernising the production structure of the industrial sector, adapting to the technological change taking place in the field of digitalisation.

The exporting net is increasingly regular: between 2014 and 2018, the number of regular exporting companies' increases, as does the volume exported and the percentage they represent in relation to the total number of exporting companies. However, the bulk of exports is still concentrated in a small number of companies, and in particular in those that export regularly.

The electric car, the highest degree of electronics incorporated in vehicles, new materials and the need to reduce costs and maintain the quality standards desired by large manufacturers are challenges faced by the productive net in Spain, which, apart from exceptions, is made up of small and medium-sized companies. Size can end up conditioning their role in an increasingly globalised sector in which accompanying large manufacturers to new markets and new R\&D projects requires capacities (financial, productive and even geographical) that smaller companies cannot always have on their own.

It can therefore be seen that market pressure has required the adoption of synergies linked to technological development (safety, communication and environmental systems, above all), reflecting the close collaboration between car and component manufacturers, who have become outstanding "players" in the market field.

We must also take into account strategies that have long been applied by large companies in the sector such as differentiation, cost leadership and distribution among others. These give way to new value chains, parallel to the traditional ones in the merely productive sphere, which will bring in new actors and competitors: technological, energy, financial, service or start-up companies as accelerators for the technological incorporation that this entails. In short, a new model that swings the balance towards a client with power, that imposes its tendencies and that demands transparency, flexibility and immediacy in the services.

In a first approximation to the subject, in the economic sector that we analyse in this work, it is observed how the strategies of incorporation of ICT in the companies of the sector is not widely applied.

It has been demonstrated on the basis of our results that the influence of ICT on TFP growth is positive, but the return on ICT investment is not significant. In this sense, Díaz-Chao and TorrentSellens (2010) do not find a causal relationship between investment in ICT and improved competitiveness of the company. It is for this reason and on the basis of the results obtained that within the Spanish automotive sector there is no direct relationship between the improvement in investment in ICT with respect to the increase in its competitive position. 
Miró-Pérez A-P., Gálvez R.C., Carreño M.V., THE AUTOMOTIVE SECTOR IN SPAIN. INFLUENCE OF R\&D INVESTMENT ON THE IMPROVEMENT OF TOTAL FACTOR PRODUCTIVITY, Zeszyty Naukowe Uniwersytetu Przyrodniczo-Humanistycznego w Siedlcach Nr 122, Seria: Administracja i Zarządzanie (49) 2019

\section{References}

Albors Garrigós, J., Collado Fuentes, A., Dols Ruiz, J.F. (2017). Factores de éxito en la clusterización de la industria del automóvil en España. El rol de los agentes en el clúster. Economía industrial, 403, 125-403.

Bloom, N., Sadun, R., Van Reenen, J. (2012). American do it better: US Multinationals and the Productivity Miracle, American Economic Review, 102, 167-201.

Bloom, N., Draca, M., Van Reenen, J. (2016). Trade induced technical change? The impact of Chinese imports on innovation, IT and productivity, The Review of Economic Studies, 83(1), 87-117.

Corrado, C., Hulten, C., Sichel, D. (2009). Intangible Capital and U.S. Economic Wealth, Review of Income and Wealth, 55, 661-685.

David, P., Foray, D. (2002). Economics fundamentals of the knowledge society. Discussion Paper No 01-14. Stanford Institute for Economic Policy Research, Stanford University.

Díaz-Chao, Á., Torrent-Sellens, J. (2010). ¿Pueden el uso de las TIC y los activos intangibles mejorar la competitividad? Un análisis empírico para la empresa catalana, Estudios de Economía Aplicada, 28(2), 1-24.

Drahos, P., Braithwaite, J. (2017). Information feudalism: Who owns the knowledge economy. Routledge.

Drucker, P. (2012). Post-capitalist society. Routledge.

Llano Molina, S. (2014). Análisis externo del sector oleícola en España. Universidad Pública de Navarra.

Martí, E.M. (2014). Caracterización y análisis del impacto y los resultados de las fusiones de cooperativas en el sector agroalimentario español. Universidad Almería.
Martín, F.J. (2013). Situación y perspectivas del sector de la automoción en España. Boletín económico de ICE, 3045, 23-34.

Miró, A.P. (2016). Dinámica de la Eficiencia Técnica e Internacionalización en el sector químico Español, Revista Galega de Economía, 25(2), 13-24.

Miró, A.P. (2018). Competitividad, Productividad y Tic. Un análisis empírico para el sector químico catalán, Revista Galega de Economía. 27(1), 49 - 64.

Morcillo, P., Alcahud, M. (2005). Creatividad que están en los cielos. Revista de Investigación en Gestión de la Innovación y Tecnología, 30, 118.

Moyano, J., Martínez, P.J., Maqueira, J.M., Bruque, S. (2012). El papel de las tecnologías de la información y las comunicaciones (TIC) en la búsqueda de la eficiencia: un análisis desde Lean Production y la integración electrónica de la cadena de suministro. Cuadernos de Economía y Dirección de la Empresa, 15(3), 105-116.

OICA. Organización Internacional de Constructores de Automóviles

Olley, S., Pakes, A. (1996). The dynamics of productivity in the telecommunications equipment industry, Econometrica, 64, 12631297.

Padilla, R., Oddone, N. (2016). Manual para el fortalecimiento de cadenas de valor. CEPAL.

Rocha, F., Aragon, J. (2012). La crisis económica y sus efectos sobre el empleo en España. Gaceta Sindical, 19, 67-90.

Sturgeon, T., Van Bieserbroeck, J. \& Gereffi, G. (2009). Value chains, networks and clusters: reframing the global automotive industry, Journal of Economic Geography, 8(3), 297-321.

\section{Annex}

Table 6. Waste statistics

\begin{tabular}{|c|c|c|c|c|c|c|c|c|c|}
\hline & \multicolumn{4}{|c|}{ Bootstrap } & & \multicolumn{4}{|c|}{ Bootstrap } \\
\hline & & Statistics & Bias & $\begin{array}{c}\text { Standard } \\
\text { error }\end{array}$ & & & Statistics & Bias & $\begin{array}{c}\text { Standard } \\
\text { error }\end{array}$ \\
\hline \multirow{5}{*}{$\begin{array}{c}\text { Forecast } \\
\text { value }\end{array}$} & Minimum & 3,1027 & & & \multirow{5}{*}{ Waste } & Minimum & $-0,7788$ & & \\
\hline & Maximum & 14,058 & & & & Maximum & 2,1175 & & \\
\hline & Medium & 7,4653 & 0,0010 & 0,4274 & & Medium & 0,0000 & 0,000 & 0,000 \\
\hline & $\begin{array}{l}\text { Standard } \\
\text { deviation }\end{array}$ & 3,0530 & $-0,040$ & 0,2875 & & $\begin{array}{l}\text { Standard } \\
\text { deviation }\end{array}$ & 0,4871 & $-0,053$ & 0,091 \\
\hline & $\mathrm{N}$ & 50 & 0 & 0 & & $\mathrm{~N}$ & 50 & 0 & 0 \\
\hline
\end{tabular}

Source: own elaboration 